\title{
Systemic complications associated with bacterial tracheitis
}

\author{
Joseph Britto, Parviz Habibi, Sam Walters, Michael Levin, Simon Nadel
}

\begin{abstract}
The toxic shock syndrome, septic shock, pulmonary oedema, and the acute respiratory distress syndrome (ARDS) were recognised in four children with bacterial tracheitis. ARDS has not previously been reported in association with bacterial tracheitis. Prompt recognition of the severe systemic complications of bacterial tracheitis could lead to a decrease in the morbidity and mortality of this condition. (Arch Dis Child 1996; 74: 249-250)
\end{abstract}

Keywords: bacterial tracheitis, acute respiratory distress syndrome, pulmonary oedema, septic shock.

Bacterial tracheitis is an uncommon but potentially life threatening infection of the trachea, distinct from both epiglottitis and viral laryngotracheobronchitis (LTB). Bacterial infection of the trachea is thought to occur secondary to a primary viral infection. ${ }^{1}$

Clinical presentation of bacterial tracheitis may be similar to both LTB and epiglottitis, but is characterised at endoscopy by the presence of a normal epiglottis, marked subglottic narrowing, and copious purulent secretions in the trachea. ${ }^{1}$ Uncomplicated viral LTB similarly may produce purulent tracheal secretions, but bacterial tracheitis is suggested by the persistence of high fever and toxicity after passage of an endotracheal tube. ${ }^{2}$ In a review of 161 reported cases of bacterial tracheitis, an artificial airway was required in $83 \%$ cases, the incidence of respiratory arrest was $11 \%$, and mortality was $3 \cdot 7 \%{ }^{3}$

Between November 1993 and March 1995 we admitted four previously healthy children with bacterial tracheitis, each associated with severe systemic complications.

\section{Case reports}

CASE 1

A 2 year old boy presented to the accident and emergency department of his local hospital with fever, barking cough, stridor, and respiratory distress. A clinical diagnosis of severe croup was made and he was treated with nebulised adrenaline to which he showed no response. Because of imminent upper airway obstruction, emergency endotracheal intubation was performed and a transfer to our paediatric intensive care unit (PICU) was requested.

On assessment by our mobile intensive care team he was tachycardic and normotensive. The core-peripheral temperature gradient was $9^{\circ} \mathrm{C}$, capillary refill time was six seconds, and he was oliguric. On auscultation, he was noted to have a gallop rhythm. He had diffuse erythroderma, non-purulent conjunctivitis, and his oral mucosa and tongue were inflamed. $\mathrm{He}$ had green watery diarrhoea. He required colloid and inotropic support and correction of metabolic acidosis and hypophosphataemia. A diagnosis of toxic shock syndrome was made and specific treatment started. $\mathrm{He}$ was extubated on day 3 .

\section{CASE 2}

A 10 year old girl presented to our accident and emergency department with fever, barking cough, shortness of breath, and a hoarse voice. On examination she had inspiratory stridor and central cyanosis with decreased air entry and bronchial breathing over the right chest. She was noted to be tachycardic and hypotensive. A clinical diagnosis of LTB and lobar pneumonia with associated septic shock was made. Emergency endotracheal intubation was performed and she was resuscitated with colloid.

On arrival in the PICU she had frank pulmonary oedema. Her central venous pressure was $5 \mathrm{~mm} \mathrm{Hg}$. She required high pressure ventilation with $100 \%$ oxygen. Echocardiography revealed a normal heart with normal left ventricular function. She was extubated on day 3.

\section{CASE 3}

A 1 year old boy presented to his local accident and emergency department with a barking cough, inspiratory stridor, severe respiratory distress, and cyanosis. Shortly after emergency endotracheal intubation, he developed frank pulmonary oedema and a transfer to our PICU was requested. On arrival of our mobile intensive care team he had features of the sepsis syndrome with tachycardia, an increased coreperipheral temperature gradient, oliguria, and metabolic acidosis. Central venous pressure was $6 \mathrm{~mm} \mathrm{Hg}$. He required colloid and inotrope treatment and high pressure ventilation with $100 \%$ oxygen. On day 3 he developed features of acute respiratory distress syndrome (ARDS). He was extubated on day 11.

\section{CASE 4}

An 11 year old boy presented to our accident and emergency department with fever, sore throat, inspiratory stridor, respiratory distress, and cyanosis. Emergency endotracheal intubation was performed. He had features of the sepsis syndrome with a core-peripheral temperature gradient of $14^{\circ} \mathrm{C}$, capillary refill time of 
Systemic complications, microbiology results from endotracheal secretions, and site of consolidation seen on chest radiography immediately after intubation in all four children

\begin{tabular}{|c|c|c|c|c|c|c|c|}
\hline \multirow{2}{*}{$\begin{array}{l}\text { Patient } \\
\text { No }\end{array}$} & \multirow{2}{*}{$\begin{array}{l}\text { Age } \\
\text { (years) }\end{array}$} & \multirow[b]{2}{*}{ Sex } & \multicolumn{3}{|l|}{ Endotracheal secretions } & \multirow{2}{*}{$\begin{array}{l}\text { Initial chest radiography } \\
\text { (location of consolidation) }\end{array}$} & \multirow{2}{*}{$\begin{array}{l}\text { Systemic } \\
\text { complications }\end{array}$} \\
\hline & & & Microscopy and Gram stain & Bacteria cultured & Viruses isolated & & \\
\hline 1 & 2 & $M$ & $\begin{array}{c}3+\mathrm{PMN}, 3+\text { Gram positive } \\
\text { cocci }\end{array}$ & $\begin{array}{l}\text { Staphylococcus aureus (TSST-1 } \\
\text { producing) }\end{array}$ & Parainfluenza 1 & Right upper lobe & Toxic shock syndrome \\
\hline 2 & 10 & $\mathrm{~F}$ & $\begin{array}{l}3+\mathrm{PMN}, 2+\text { Gram positive } \\
\text { cocci, } 1+\text { Gram negative rods }\end{array}$ & Streptococcus pneumoniae & Negative & $\begin{array}{l}\text { Right upper and middle } \\
\text { lobe }\end{array}$ & $\begin{array}{l}\text { Septic shock, pulmonary } \\
\text { oedema }\end{array}$ \\
\hline 3 & 1 & $\mathbf{M}$ & $\begin{array}{c}3+\text { PMN }, 1+\text { Gram positive } \\
\text { cocci }\end{array}$ & Normal flora & Parainfluenza 3 & $\begin{array}{l}\text { Right upper and middle } \\
\text { lobe }\end{array}$ & $\begin{array}{l}\text { Sepsis syndrome, pulmonary } \\
\text { oedema, ARDS }\end{array}$ \\
\hline 4 & 11 & $\mathbf{M}$ & $\begin{array}{l}3+\text { PMN }, 2+\text { Gram positive } \\
\text { cocci, } 1+\text { Gram negative cocci }\end{array}$ & Staphylococcus aureus & Negative & Right upper lobe & Sepsis syndrome \\
\hline
\end{tabular}

$\mathrm{PMN}=$ polymorphonuclear leucocytes. $\mathrm{TSST}=$ toxic shock syndrome toxin.

eight seconds, and oliguria. He required resuscitation with colloid and inotropes. $\mathrm{He}$ was extubated on day 6 .

All four children had significant subglottic oedma suggested by the absence of an air leak around an endotracheal tube of a size smaller than that predicted by the child's age. The epiglottis was noted to be normal and copious purulent secretions were obtained from the trachea in each case. The results of microbiological tests performed on endotracheal secretions have been summarised in the table. All patients were treated with parenteral flucloxacillin and cefotaxime.

\section{Discussion}

Bacterial tracheitis is an important cause of acute upper airway obstruction in children. Although frequently recognised and treated as such with stabilisation of the airway, what is not often recognised is that there may be severe associated clinical features, which if left untreated, may significantly compromise the clinical status of the child.

All our cases had features of the sepsis syndrome with or without shock, and required volume, and in some cases inotropic support and correction of metabolic derangements.

Case 1 was associated with the toxic shock syndrome. Bacterial tracheitis is now considered a high risk setting for toxic shock syndrome in children. ${ }^{4}$ Management of toxic shock syndrome includes systemic antibiotics to kill toxin-producing organisms, and aggressive removal of the source of the toxin. This may be achieved by frequent suctioning of purulent secretions and tracheal toilet.

Pulmonary oedema occurred in cases 2 and 3 shortly after relief of upper airway obstruction after intubation. The incidence of pulmonary oedema has been reported to be as high as $12 \%$ in patients intubated for croup or epiglottitis. ${ }^{5}$ Putative pathogenic mechanisms for pulmonary oedema include rapid changes in intrathoracic pressure, pulmonary vascular endothelial injury due to hypoxia or infection, aspiration of gastric contents, and left ventricular failure. ${ }^{5}$

In case 3 , the clinical course was complicated by the development of ARDS. There are no published reports of ARDS occurring in association with bacterial tracheitis. There were several possible precipitating events for ARDS in our patient. Parainfluenza virus type 3 infection could have precipitated ARDS and both pneumonia and pulmonary aspiration are well recognised causes of ARDS. ${ }^{6}$ Our case had clinical and radiographic evidence of pneumonia, and pulmonary aspiration could not be ruled out. Furthermore, it is possible that the upper airway obstruction and subsequent pulmonary oedema may have precipitated ARDS in our patient.

In conclusion, the presence of severe systemic complications has not previously been recognised as a frequent feature of bacterial tracheitis. Prompt recognition of these complications could lead to a decrease in the appreciable morbidity and mortality of bacterial tracheitis.

The authors appreciate the clinical assistance of Professor Simon Kroll. Dr J Britto is supported by the George John Livanos Charitable Trust.

1 Donnelly BW, McMillan JA, Weiner LB. Bacterial tracheitis: report of eight new cases and review. Rev Infect Dis 1990; 12: 729-35.

2 Phelan PD, Landau LI, Olinsky A. Clinical patterns of acute respiratory infection. In: Respiratory illness in children. 3rd Ed. Oxford: Blackwell Scientific Publications, 1990: 47-88.

3 Gallagher PG, Myer CM. An approach to the diagnosis and treatment of membranous laryngotracheobronchitis in infants and children. Pediatr Emerg Care 1991; 7: 337-42

4 Resnick SD. Staphylococcal toxin-mediated syndromes in childhood. Semin Dermatol 1992; 11: 11-8.

5 Kanter RK, Watchko JF. Pulmonary edema associated with upper airway obstruction. Am $\mathcal{F}$ Dis Child 1984; 138 356-8.

6 Fowler AA, Hamman RF, Good JT. Adult respiratory distress syndrome: risk with common predispositions. Ann Intern Med 1983; 98: 593-7. 